\title{
Machado de Assis, \\ o Instinto de \\ Nacionalidade e Nós
}

E ugénio Lisboa*

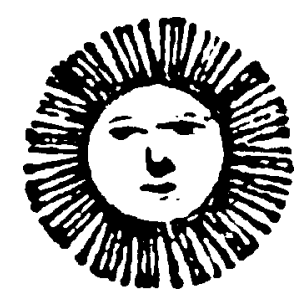

* Crítico, poeta e ensaísta português. 
«Todas as nações», dizia Valéry, «têm razões presentes, passadas ou futuras para se julgarem incomparáveis.» As razões são, umas vezes, mais fundamentadas, outras vezes, menos. Mas aqueles que as têm ou julgam tê-las, vivem-nas, frequentemente, com convicção e até com acinte. De aí quererem preservar, não raro, com vigor, a pureza química daquilo que têm por sua nacionalidade. E que vigiem, com desconfiança, os elementos supostamente mais impuros que se queiram inculcar como parte (ilegalmente) integrante do corpus nacional.

Nascido em Moçambique, como tantos outros europeus de passaporte português e de cultura africana e universal, não poucas vezes, ao longo do meu percurso de cidadão e de escritor tenho deparado com a pergunta disparada, ora com fragor, ora com amizade: «Você é português ou moçambicano?» $\mathrm{U}$, de modo mais claro: «Você considera-se moçambicano?» O u ainda mais perfidamente: «Você acha que pode ser considerado moçambicano?».

Este tipo de pergunta é-me feita, por terceiros, com muito mais frequência, depois que M oçambique, em 1975, se tornou independente. Mas era-me feita, por mim próprio, com intensidade ealguma angústia, sobretudo antes - e mesmo muito antes - daquele ano-charneira.

Não poucos de nós não só ali vivendo, mas ali nascidos e ali tornados pais de filhos e filhas ali também radicados, não poucos de nós, repito, ali fruindo a largueza e generosidade daqueles espaços e sintonizando o nosso viver ao ritmo vagaroso daquele estar no mundo e daquele haver tempo para tudo, até para o conviver saboroso e para a leitura demorada e apetecida, não poucos de nós nos interrogávamos sobre a profundidade do nosso enraizamento africano ou sobre a classificação possível que nos cabia, em termos de nacionalidade. Portugueses 
provisoriamente em Moçambique? Mas o provisório era Portugal onde só íamos de férias e onde não tínhamos família que se visse. Moçambicanos, então, que às vezes iam à metrópole, como nessa altura se dizia? Mas tantos dos nossos valores culturais eram portugueses! Tantos dos nossos amigos, escritores ou não, viviam em Lisboa, ou no Porto, ou em Coimbra! Alimentávamo-nos tão quotidianamcnte de Eça, de Camito, de Pessoa, de Camões, de Régio e de tantos outros que nada ou quase nada tinham com a África que nos fora berço!

\section{Que fazer? Escolher? Mas escolher, como?}

As coisas complicar-se-iam, comigo, depois da independência, que me precipitou, via J ohannesburg e Estocolmo, em Londres onde vim a residir mais anos (dezassete) do que aqueles que tenho, tudo somado, de vivência em Portugal. U ma L ondres onde me sinto hoje em casa, cheio de raízes e de afectos e de espaços que ficaram meus. Então em que ficamos: moçambicano, português ou inglês? O problema não é fácil e, vendo-me com tantas e gostosas raízes, mais inclinado me sinto a declarar, com alguma grandiloquência, na esteira de Wells: «O ur true nationality is mankind». M as penso cada vez mais que, para se ser verdadeiramente do mundo - para sê-lo com veracidade, com apetência, com alegria, com voracidade - há que ser-se enraizado algures. Viaja-se melhor quando se parte de algum lado a que se pode regressar. M as será esse algum lado um só lado, ou poderá ser mais do que um? Como definir a nossa nacionalidade, a nossa origem, o nosso ponto de arranque e de regresso? Quando, hoje, volto a Moçambique, sinto-me em casa. O mesmo sinto em Londres e em Lisboa. Desenraizado ou multi-enraizado? Desprovido de raízes ou milionário de raízes?

Quando estávamos cm Moçambique, antes de virem as convulsões - mas sabendo que elas viriam porque tinham que vir - estes problemas, embora não ainda com o mesmo complexo perfil, atormentavam-nos já. E foi então que tomámos conhecimento, por via da sugestão de um grande escritor português, que visitou M oçambique em 1972, do texto seminal de M achado de Assis, «N otícia da Atual Literatura Brasileira. Instinto de Nacionalidade». O texto, para ponto inicial de reflexão, é, invulgarmente sereno, pouco demagógico, reflectido e nuançado. «Quem examina a atual literatura brasileira reconhece-lhe logo, como primeiro traço, certo instinto de nacionalidade», assim começa $\mathrm{M}$ achado que, ao remeter o problema para uma questão de «instinto», de um só golpe evita tanto teorizar estéril e quase sempre votado à má fé, ao malabarismo coxo e, em última análise, ao fracasso. «Poesia, romance, todas as formas literárias do pensamento buscam vestir-se com as cores do país, e não há negar que semel hante preocupação é sintoma de vitalidade e abono de futuro», continua o autor de Brás Cubas, logo acrescentando: « nterrogando a vida brasileira e a natureza americana, pro- 
sadores e poetas acharão ali farto manancial de inspiração e irão dando fisionomia própria ao pensamento nacional». Mas concluía, com a cautela própria de quem pressente a complexidade e as armadilhas que espreitam conceitos tão delicados como o de nacionalidade: «E sta outra independência não tem Sete de Setembro nem campo de I piranga; não se fará num dia, mas pausadamente, para sair mais duradoura; não será obra de uma geração nem duas; muitas trabalharão para ela até perfazê-la de todo.» Por outras palavras, e com toda a força que o pensamento de $M$ achado reveste mas o seu suave formular matiza, por outras palavras, as identidades não se fabricam da noite para o dia. Nem o Sete de Setembro, no B rasil, nem o 25 de J unho, em M oçambique, fabricam instantaneamente, por milagre acontecido, no primeiro caso, a brasilidade, no segundo, a moçambicanidade. Trata-se, como precisa o autor de Quincas Borba, de um processo lento, pausado, que «não será obra de uma geração nem duas.» O caminho para a descoberta de uma nacionalidade própria tem os seus perigos: um deles é o excesso, o frenesi, o risco da exaltação fora de controle, a derrapagem chauvinista, o ódio ao que não é nacional, daquela nacionalidade acabada de inventar e por isso fresquinha e intolerante: «O nacionalista», notava Gide, «tem um ódio vasto e um amor estreito». O instinto de nacionalidade, se a si próprio se pressente ainda frágil e vulnerável, pode volver-se facilmente idolatria e fanatismo: «O nacionalismo», observava, com agudeza, Erich Fromm, «[o nacionalismo] é a nossa forma de incesto, a nossa idolatria, a nossa insanidade.» M achado, fino, subtil, cauteloso, faz, pois, uma navegação sofisticada e matizada: «Sente-se aquele instinto [ de nacionalidade], diz ele, «até nas manifestações da opinião, aliás mal formada ainda, restrita em extremo, pouco solícita e ainda menos apaixonada nestas questões de poesia e literatura. Há nela um instinto que leva a aplaudir principalmente as obras que trazem os toques nacionais. A juventude literária, sobretudo», nota ele, «faz deste ponto uma questão de legítimo amor-próprio.» M as logo se sente na necessidade de observar: «Nem toda ela [a juventude literária] terá meditado os poemas de Uruguai e Caramuru com aquela atenção que tais obras estão pedindo; mas os nomes de B asílio da G ama e D urão são citados e amados, como precursores da literatura brasileira. A razão é que eles buscaram em roda de si os elementos de uma poesia nova, e deram os primeiros traços de nossa fisionomia literária, enquanto que outros, G onzaga por exemplo, respirando aliás os ares da pátria, não souberam desligar-se das faixas da Arcádia [leia-se: de Portugal] nem dos preceitos do tempo. «Admira-se-Ihes o talento», nota M achado, com ironia, «mas não se Ihes perdoa o cajado e a pastora, e nisto há mais erro que acerto.»I sto é, embora simpatizando com o exercício do instinto de nacionalidade, nos jovens leões da literatura brasileira, M achado rejeita liminarmente, desde logo, qualquer fundamentalismo nacionalista, esconjurando, de pronto, o risco daquele incesto, daquela idolatria e 
daquela insani da de a que aludira o já citad o E rich F romm. O seu «reconhecimento» do instinto de nacionalidade é, insisto, reafirmado, sem equívocos, quando diz: «M eu principal objecto é atestar o fato actual; ora, o fato é o instinto de que falei, o geral desejo de criar uma literatura independente.»

Pensando, no entanto, talvez em si próprio e na sua literatura não carregada em excesso de cor local, M achado leva mais longe o seu colocar de fusíveis contra o possível advento de qualquer fundamentalismo de cor local: «D evo acrescentar», observa ele, no texto famoso, «que neste ponto manifesta-se às vezes uma opinião que tenho por errónea: é a que só reconhece espírito nacional nas obras que tratam de assunto local, doutrina que, a ser exacta, limitaria muito os cabedais da nossa literatura.» E , logo adiante, M achado não hesitava em oferecer esta formulação enfática: «Não há dúvida que uma literatura, sobretudo uma literatura nascente, deve principalmente alimentar-se dos assuntos que Ihe oferece a sua região; mas não estabel eça mos doutri nas tão absurdas que a empobreçam. O que se deve exigir do escritor antes de tudo, é certo sentimento íntimo, que o torne homem do seu tempo e do seu país, ainda quando trate de assuntos remotos no tempo e no espaço. Um notável crítico da França, analisando há tempos um escritor escocês, M asson, com muito acerto di zi a que do mesmo modo que se podia ser bretão sem falar sempre de tojo, assim Masson era bem escocês, sem di zer palavra de cardo, explicava o di to acrescentando que «havia nel e um scotti smo interi or, diverso e melhor do que se fora apenas superficial.» ( O grifo é nosso)

Num momento em que a literatura brasileira arrancava para uma esplêndida estatura de autonomia, para um explodir de identidade própria, fazer este tipo de reparos exigia, a um tempo, lucidez e coragem. E m momentos de exaltação ebulitiva, faz sempre falta uma cabeça sólida e intrépida que não permita reducionismos fundamentalistas ou, tendo de os haver, que permita diminuir-lhes os estragos. M achado de Assis foi essa cabeça sólida e intrépida.

Para alguns dos que, em 1975, viviam, em M oçambique, momentos de euforia libertadora e de uma excitada afirmação de identidade nacional, um fundamentado receio começava a desenhar-se quanto ao futuro acolhimento que se iria dar (ou retirar) a notáveis poetas como, por exemplo, R einaldo Ferreira, G lória de Sant'Ana ou Rui K nopfli. Se, das classicamente decantadas poesias destes, a cor local se não ausentara de todo, a marca de universalidade (que não de intemporalidade) prevalecia apesar de tudo. Tentações terá havido - não durante muito tempo, verdade seja dita - de se relegar para segund o plano ou para outras latitudes algumas das obras mais notáveis que a Poesia até então produzira em M oçambique. Que essas obras eram, por sua natureza e qualidade, altos produtos representativos de uma dupla identidade ou nacionalidade, ou seja, corolário de um instinto de nacionalidade bifronte - não merecia dúvidas a alguns de nós. 0 
«moçambicano ou português» deveria - parecia evidente - ser substituído, com vantagem operatória, pelo «moçambicano e português». Com o seu conceito simples e eficaz de tudo remeter para o «instinto», Machado delegava nos autores mesmos - e não noutros por eles - a decisão de se atribuírem a nacionalidade que melhor lhes parecesse. Diante deste dispositivo genialmente simples, como nos pareceram então e nos parecem ainda hoje artificiais e até caricaturáveis as fórmulas de africanidade, de angolanidade e de moçambicanidade propostas por pseudo-teóricos que muito pouco ou nada sintonizam quer com a literatura, quer com o referente que Ihes subjaz.

A sondagem perspicaz e firme de Machado serviu-nos então de bordão de apoio. Como gostávamos de ouvi-lo e nos sentíamos vingados, quando líamos coisas como esta: «E stes e outros pontos cumpria à crítica estabelecê-los, se tivéssemos uma crítica doutrinária, ampla, elevada, correspondente ao que ela é em outros países.» $A$ verdade, porém, é que, «uma crítica doutrinária, ampla, elevada», como queria Machado de Assis, é um milagre que leva tempo a acontecer e que, depois de ter acontecido, só volta a acontecer muito tempo depois. O que é bom cresce devagar. Mas sabe bem ter quando um dia aparece para nos iluminar e nos redimir.

Lisboa, Novembro de 1997. 